Mabasan, Vol. 1, No. 2, Juli-Desember 2007: 1-16

\title{
Distribusi dan Pemetaan Varian-Varian Bahasa Bali di Kabupaten Dompu
}

\author{
Dewi Nastiti L*
}

\begin{abstract}
Abstak
Makalah ini mengkaji disribusi dan pemetaan varian-varian bahasa Bali di Kabupaten Dompu dengan menggunakan pendekatan dialektologi diakronis.

Ada empat kantong bahasa (enklave) yang didiami oleh etris Bali yang bertransmigrasi di Kabupaten Dompu, yaitu di desa So Nggajah, Desa Taropo, Desa Mada Jumba, dan Desa Simpasai.

Bahasa Bali yang ada ada di Kabupaten Dompu memiliki empat dialek Taropo (DT), dialek So Nggajah (DS), dialek Simpasai (DSim), dan dialek Mada Jumba (DMj). Keempat dialek ini tidaklah langsung diturunkan sekaligus dari prabahasa BaliDompu. Terdapat dua Fase perkembangan historis dari dari PBBL (Prabahasa Bali) menjadi empat dialek BBL (Bahasa Bali ), yaitu fase pertama BFLD (Bahasa BaliDompu) pecah ke dalam dua dialek, yaitu dialek Taropo So Nggajah Simpasai (DTSSim) dan dialek Mada Jumba (DMj). Pada fase kedua adalah pecahnya DTSSim (dialek Taropo So Nggajah Simpasai ) menjadi tiga dialek, yaitu dialek Taropo, dialek So Nggajah, dan dialek Simpasai).
\end{abstract}

Kata Kunci: varian-varian bahasa, dialektometri, dan kantong bahasa (enklave)

\section{Pengantar}

Keberagaman adat istiadat, khususnya bahasa harus tetap dipertahankan sedini mungkin berkaitan dengan kesatuan yang sudah dicetuskan dalam perwujudan Negara Kesatuan Republik Indonesia. Oleh sebab itu, upaya pemertahanan bahasa salah satunya dapat dilakukan dengan memetakan seluruh bahasa yang ada di Indonesia. Rangkaian upaya pemertahanan bahasa melalui pemetaan bahasa tersebut merupakan bagian terpenting dari tujuan penelitian bahasa ini.

Usaha penelitian tentang kantong bahasa di NTB perlu dilakukan agar dapat memeperlihatkan gambaran mengenai etnis pemakai bahasa tertentu yang lambat laun dapat mengalami perubahan disebabkan interaksi dengan lingkungan sekitar. Begitu halnya dengan kajian mengenai Distribusi Bahasa Bali di Dompu menarik untuk dilakukan mengingat belum ada penelitian terdahulu yang mengkaji bahasa Bali di Dompu.

Seperti yang sudah disinggung di atas, masalah isolek Bali di Dompu belum ada yang meneliti dan penelitian ini menarik untuk dikaji mengingat penutur isolek Bali di Dompu hidup berdampingan dengan penutur bahasa Mbojo atau pun penutur bahasa daerah lainnya. Keadaan seperti itu akan menyebabkan kontak bahasa dan dapat menimbulkan saling mempengaruhi atau saling meminjam satu sama lain. Dengan 
Mabasan, Vol. 1, No. 2, Juli-Desember 2007: 1-16

demikian, isolek Bali-Dompu diprediksikan akan mengalami perubahan-perubahan dalam aspek kebahasaan, khususnya fonologi dan leksikon. Penelitian mengenai distribusi bahasa Bali di Dompu ini ditekankan pada kajian dialektologi diakronis. Pada akhirnya, penelitian ini memperlihatkan peta yang berkaitan dengan penentuan batas isolek yang dalam hal ini dialek bahsa Bali-Dompu beserta pengenalannya pada enklave Bali-Dompu, dan memperlihatkan pula pohon kekerabatan dialek-dialek prabahasa Bali di Dompu.

Penelitian ini menerumuskan beberapa masalah yang berkenaan dengan variasi bahasa Bali di Dompu, hubungan kekerabatan antarvarian bahasa Bali di Dompu, jumlah penutur pada daerah kantong bahasa Bali di Dompu, sebaran distribusi geografis bahasa Bali di Dompu, beserta pengenalan masing-masing isolek.

Metode yang dalam penelitian ini menggunakan pendekatan dialektologi diakronis yang meliputi metode kuantitatif berupa perhitungan dialektometri dan digunakan pula bukti kualitatif untuk mendukung perhitungan dialektometri tersebut.

\section{Pembahasan}

\subsection{Penentuan Isolek}

Dalam bagian ini, akan dilakukan penentuan isolek sebagai dialek atau subdialek. Hal ini dimaksudkan supaya diperoleh gambaran yang jelas mengenai hubungan yang terdapat anatarisolek yang digunakan pada setiap daerah pengamatan.

Dari tabulasi tahap II di atas, terlihat dialek yang dapat menyatukan daerah pengamatan. Penentuan pemilihan daerah pengamatan berdasarkan dialek tersebut dapat diketahui dengan menghitung jumlah perbedaan dari 400 data antardaerah. Dengan berpijak pada perhitungan dialektometri, dapat dikatakan bahwa bahasa Bali memiliki empat dialek yaitu: dialek Taropo (DT), dialek So Nggajah (DS), dialek Mada Jumpa (DMJ ), dan dialek Simpasai (DSim).

Penentuan kriteria isolek menjadi sebuah dialek di atas didasarkan perhitungan dialektometri yang merupakan metode yang bersifat kuantitatif. Adapun hasil perhitungan dialektometri sebagai berikut.

$\begin{array}{cc}\text { Persentase } & \text { Dialektometri } \\ 1-2 & 58,86 \% \\ 1-3 & 67,08 \% \\ 1-4 & 70,25 \% \\ 2-3 & 63,29 \% \\ 2-4 & 56,33 \% \\ 3-4 & 77,22 \%\end{array}$


Dari hasil persentase dialektometri di atas, dapat dikatakan bahwa daerah pengamatan 1 sampai dengan 4 merupakan kriteria perbedaan dialek. Selain itu, peneliti juga menggunakan metode berkas isoglos yang cenderung bersifat kaulitatif karena daerah yang dipersatukan oleh isoglos itu berupa daerah yang mengalami inovasi bersama yang bersifat eksklusif dalam merefleksikan suatu bentuk prabahasa.

Isoglos yang mempersatukan daerah-daerah dialek di atas dapat dijelaskan sebagai berikut. Untuk DT, dari 162 buah peta yang diperbandingkan terdapat 58 buah isoglos yang menyatukan daerah pengamatan 1 dan sekaligus membedakannya dengan daerah pengamatan lainnya yang tidak sedialek denganyan. Dari 58 isoglos, terdapat satu korespondensi kurang sempurna. Adapun yang menyatukan daerah pengamatan DS terdapat 33 buah isoglos yang menyatukan daerah pengamatan 2 dan sekaligus membedakannya dengan daerah pengamatan lainnya yang tidak sedialek dengannya. Untuk daerah pengamatan DMJ, terdapat 53 buah isoglos yang menyatukan daerah pengamatan 3 dan dan sekaligus membedakannya degan daerah pengamatan lainnya yang tidak sedialek dengannya. Selanjutnya, untuk daerah pengamatan DSim terdapat 54 isoglos yang menyatukan daerah pengamatan 4 dan sekaligus membedakannya dengan daerah pengamatan lainnya.

Berkenan dengan hal itu, pada daerah pengamatan DSim yang memiliki 33 isoglos untuk menyatukan daerah pengamatan, tidak sesuai dengan kriteria penentuan isolek sebagai dialek karena dalam kriteria tersebut. isolek ini termasuk dalam kriteria perbedaan subdialek. Hal ini mungkin terjadi berkenaan dengan situasi kebahasaan masing-masing daerah. Apabila, ditilik kembali penerapan metode isoglos dalam pemilahannya menjadi dialek atau subdialek, metode tersebut disusun atas pertimbangan saran dari Tawangsih Lauder (1990) tentang modifikasi persentase yang sudah diusulkan Guiter (1973) dalam dialektometri. Oleh sebab itu, dalam hal ini peneliti hanya memakai metode dialektometri yang didukung dengan bukti-bukti kualitatif sebagai penentuan isolek Bali menjadi sebuah dialek di Dompu.

\subsection{Penentuan Hubungan Kekerabatan}

Dari bukti-bukti yang sudah dipaparkan sebelumnya, bahasa Bali-Dompu memiliki 4 dialek, yaitu dialek Taropo (DT), dialek So Nggajah (DS), dialek Simpasai (DSim), dan dialek Mada Jumba (DMJ). Keempat dialek ini tidaklah langsung diturunkan sekaligus dari prabahasa Bali-Dompu. Peneliti sudah membuktikan bahwa munculnya keempat dialek bahasa Bali tersebut melalui jenjang kekerabatan yang 
bertingkat-tingkat, seperti dapat dilihat pada pohon kekerabatan dialek-dialek prabahasa Bali di Dompu berikut ini.

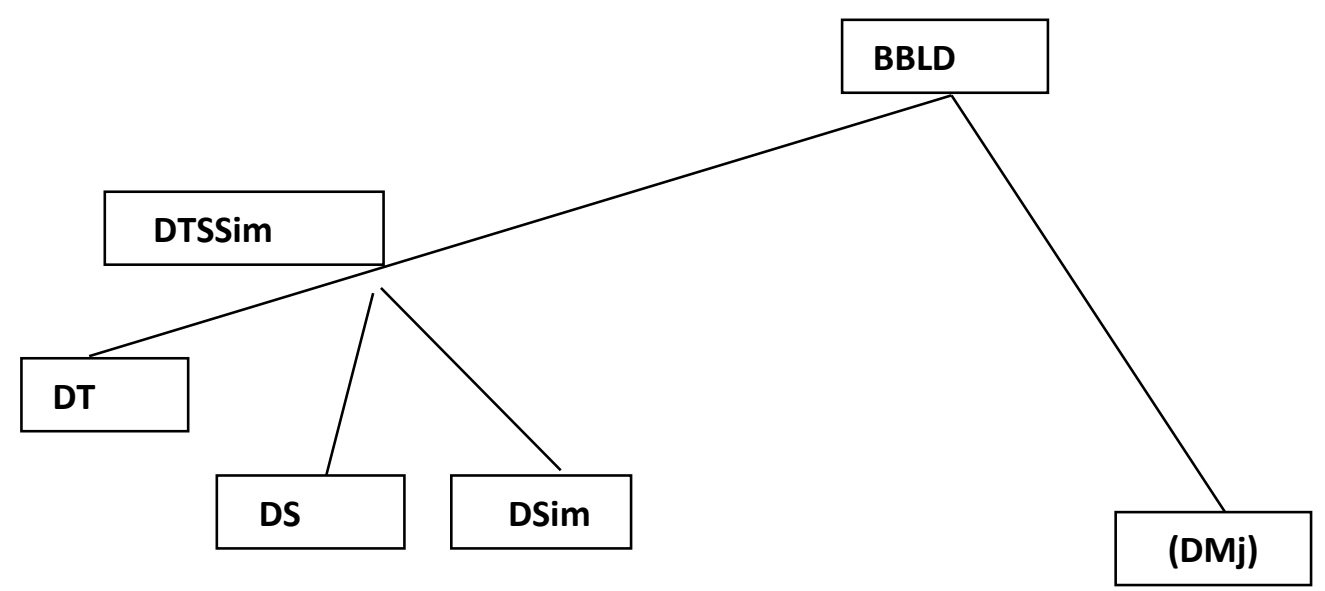

Pada pohon kekerabatan di atas, terlihat bahwa terdapat dua fase perkembangan historis dari PBBL menjadi 4 dialek BBL, yaitu fase pertama BBLD pecah ke dalam dua dialek, yaitu dialek Taropo So Nggajah Simpasai (DTSSim) dan dialek Mada Jumba (DMJ), dan fase kedua adalah pecahnya DTSSim menjadi tiga dialek, yaitu dialek Taropo, dialek So Nggajah, dan dialek Simpasai. Pembuktian tersebut didasarkan atas unsur kedekatan antar dialek yang dihitung berdasarkan persentase terkecil dari hasil dialektometri seperti seperti dalam tabel ini.

\begin{tabular}{|l|l|}
\hline \multicolumn{2}{|c|}{$\begin{array}{c}\text { Persentase Dialektometri yang akan } \\
\text { Membawa pada Hubungan Kekerabatan }\end{array}$} \\
\hline $1---2$ & $58,86 \%$ \\
\hline $1---4$ & $70,25 \%$ \\
\hline $2---4$ & $56,33 \%$ \\
\hline Rata-rata & $\mathbf{6 1 , 8 1 \%}$ \\
\hline $1---3$ & $67,08 \%$ \\
\hline $2---3$ & $63,29 \%$ \\
\hline $3---4$ & $77,22 \%$ \\
\hline Rata-rata & $\mathbf{6 9 , 1 9 \%}$ \\
\hline
\end{tabular}

Selain itu, pula terdapat bukti kualitatif berupa pernyataan dan dialek Taropo So Nggajah Simpasai (DTSSim) yang diwakili oleh daerah pengamatan1,2,4 dan dialek Mada Jumba (DMJ) yang diwakili oleh daerah pengamatan 3. 
Mabasan, Vol. 1, No. 2, Juli-Desember 2007: 1-16

\subsection{Jumlah Penutur Bahasa Bali-Dompu}

Jumlah penutur bahasa Bali-Dompu didasarkan atas perhitungan yang telah dilakukan oleh Badan Biro Pusat Statistik (BPS) dan data dari Kelurahan Desa. Berkaitan dengan perhitungan tersebut, dapat diketahui jumlah penutur dialek Taropo sebesar 1.506 jiwa, dialek So Nggajah sebesar 546 jiwa, dialek Mada Jumba sebesar 3.292 jiwa, dan dialek Simpasai sebesar 6.762 jiwa.

\subsection{Peta geografis daerah pakai yang memiliki variasi dialektal}

Variasi Dialektal Bahasa Bali di

Kabupaten Dompu

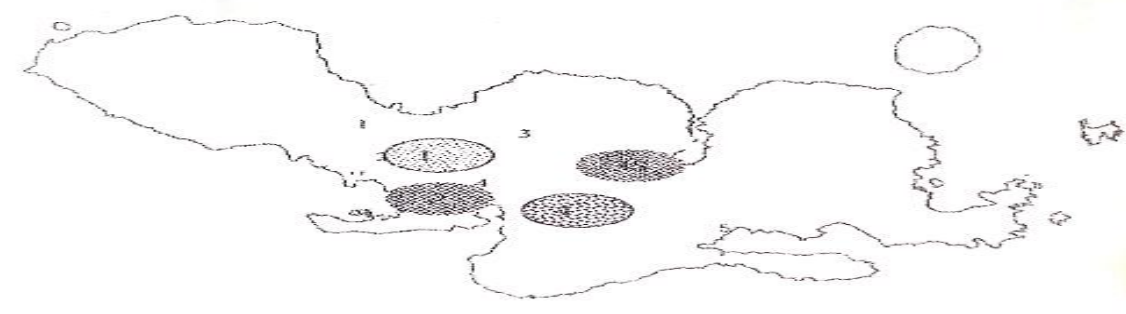

\section{Keterangan}

:?::?::

= dialek Taropo

登然然

= dialek So Ngajah

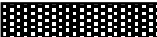

= dialek Mada Jumba

=dialek Simpasi 
Mabasan, Vol. 1, No. 2, Juli-Desember 2007: 1-16

\subsection{Pengenalan Dialek Baham Bali Dompu}

Setelah diketahui empat dialek bahasa Bali di Dompu berdasarkan hasil perhitungan dialektometri, pada bagian ini akan dilakukan penelaahan mengenai sistem fonologi pada keempat dialek tersebut. Telaah yang dimaksud menyangkut pendeskripsian sistem fonologi masing-masing dialek. Hanya beberapa bidang kebahasaan fonologi merupakan bidang yang dijadikan titik awal mengetahui cirri-ciri perubahan dalam satu bahasa.

Selain itu, mengingat pembahasan yang ingin dicapai dalam penelitian ini adalah mengindentifikasi bentuk-bentuk bahasa yang berkerabat, maka cirri-ciri fonologi menjadi utama untuk dipaparkan. Hal itu disebabkan rekonsruksi bahasa purba nanti yang melihatkan bentuk-bentuk berkerabatan hanya mungkin terjadi bila ciri-ciri perubahan fonologinya sudah teridentifikasi secara lengkap.

\subsubsection{Fonologi Dialek Taropo (DT)}

Deskripsi sistem fonologi DT menyangkut inventarisasi dan disribusi fonem yang akan dipaparkan satu per satu berikut ini.

\subsubsection{Inventarisasi vonem}

Fonem-fonem dalam dialek Taropo pada dasarnya dapat dikelompokkan menjadi dua bagian, yaitu vokal dan konsonan. Sistem vokal dialek ini tersusun dalam 8 fonem vokal, seperti terlihat pada bagan berikut ini.

\section{Bagan Vokal Dialek Taropo}

\begin{tabular}{|c|c|c|}
\hline I & & u \\
\hline $\mathrm{e}$ & $\mathrm{a}$ & $\mathrm{U}$ \\
$\mathrm{E}$ & & $\mathrm{O}$ \\
\hline & & $\mathrm{O}$ \\
\hline & & \\
\hline
\end{tabular}


Pembuktian akan status fenomenis kesembilan vokal di atas dilakukan dengan menunjukkan pasangan minimal dari fonem-foenm tersebut dan untuk fonem-fonem yang tidak ditemukan pasangan minimalnya dilakukan dengan menunjukan distribusi lengkap akan dijadikan fonem yang berdiri sendiri.

Langkah selanjutnya, konsonan dalam dialek ini tersusun dalam sistem sebanyak 19 buah fonem, seperti terlihat pada gambar bagan konsonan berikut.

\section{Bagan Konsonan Dialek Taropo}

\begin{tabular}{|c|c|c|c|c|c|c|c|c|c|}
\hline \multicolumn{2}{|c|}{ Jenis } & \multicolumn{8}{|c|}{ Daerah Artikulasi } \\
\hline & & \multirow{3}{*}{$\begin{array}{l}\frac{\text { Labial }}{\text { Labial }} \\
\frac{\mathrm{P}}{}\end{array}$} & \multicolumn{2}{|c|}{ Dental } & \multicolumn{2}{|c|}{ Alveolar } & \multirow{2}{*}{$\begin{array}{c}\text { Palatal } \\
\text { Laminal }\end{array}$} & \multirow{2}{*}{$\begin{array}{c}\text { Velar } \\
\text { Dorsal }\end{array}$} & \multirow[t]{2}{*}{ Glotal } \\
\hline & & & Labial & Apikal & Apikal & Laminal & & & \\
\hline \multirow[t]{2}{*}{ Hambat } & $\mathrm{TS}$ & & & $\mathrm{T}$ & & & $\mathrm{c}$ & $\mathrm{k}$ & $\mathrm{Q}$ \\
\hline & $\mathrm{BS}$ & $\mathrm{B}$ & & $\mathrm{d}$ & & & $\mathrm{j}$ & $\mathrm{g}$ & \\
\hline \multirow{2}{*}{$\begin{array}{c}\text { Geser/ } \\
\text { Frikatif }\end{array}$} & TS & & & & & $S$ & & & $\mathrm{H}$ \\
\hline & $\mathrm{BS}$ & & & & & & & & \\
\hline Nasal & & $\mathrm{M}$ & & $\mathrm{n}$ & $\mathrm{n}$ & $\mathrm{N}$ & & & \\
\hline Lateral & & & & 1 & & & & & \\
\hline Getar & & & & $\mathrm{r}$ & & & & & \\
\hline $\begin{array}{l}\text { Semi } \\
\text { Vokal }\end{array}$ & & $\mathrm{W}$ & & & $\mathrm{y}$ & & & & \\
\hline
\end{tabular}

\subsubsection{Distribusi Fonem}

Vokal-vokal dalam dialek ini dapat menempati posisi awal, tengah, dan akhir. Khusus untuk fonem /u/ yang memiliki alofon/u/ dan/U/, keduanya memiliki perbedaan posisi silabe. Alofon [u] dapat muncul dalam posisi terbuka, sedangkan alofon $[\mathrm{U}]$ hanya dapat muncul dalam posisi tertutup. Lebih jelasnya berikut ini akan ditampilkan contoh disribusi dialek Taropo.

/i/ : : ipUn 'a', piran 'dengar', banih 'benih', gani 'api'.

/u/ : : ntu 'gigi', akuda 'beberapa', wawu 'baru'.

/U/ : : Uka 'anak', balUs 'basah'.

le/ : ekoh 'ekor' pepetan 'kutu', nacen 'beri', jEleme 'orang'.

/o/ : odah 'nenek', tonjos 'gigi yang menonjol keluar', kacog 'mati', koko 'gigit'.

/E/ : Endep 'rendah', marErEn 'baring', raganE 'engkau'.

/U/ : : /U/nUh 'Ompong', bUkUn 'pinggul', dikU ',itu'.

/a/ : alak 'malu', basa 'bengkak', pa 'paha'.

/a/ : aji 'ayah', jalati 'cacing', nankuda 'tungku'.

Selain vokal, konsonan dalam dialek ini hampir semuanya dapat menempati posisi awal, tengah, dan akhir kata. Ada beberapa konsonan yang tidak bisa menempati posisi akhir seperti /c/,/j/,/n/,/w/,/y/, dan konsonan yang tidak bisa menempati posisi antepenultima dan penultima seperti /q/ dan/h/. Masing-masing contoh berikut diharapkan dapat memeperjelas distribusi konsonan dalam dialek ini. 
/b/ : balig 'licin', labuh 'jatuh', rab 'atap; 1 '.

/p/ : paksi 'burung', papapat 'empat', murip 'hidup'.

/t/ : toh 'kering', enton 'perut', nabot 'kiri'.

/d/ : : dUh 'jauh', nadak 'cium', kampid 'sayap'

/c/ : cunuh 'hidung', bacik 'baik'

/j/ : : jalati 'cacing', majuluk 'berdiri', jagut 'dagu'

/k/ : : kanah 'hati', makabar 'terbang', kadek 'tertawa'

/g/ : : gegr 'punggung', nadug 'berdiri'

/q/ : : matuaq 'bawah', 'mertua'

/s/ : : : samba 'lumbung', kasab 'kasar', kadas 'bersih'

/h/ : : mankihan 'nafas', aluh 'gampang'

$/ \mathrm{m} / \quad$ : memek 'ibu', nalamasin 'perajut', salam 'hitam'

/n/ : nulut 'dorong', kanawan 'kanan', nacen 'beri'

/n/ : nunun 'berenang', malingih 'duduk'

li/ : lingah 'lebar', alit 'kecil', malali 'main', pangal 'geraham'

/r/ : ririh 'cekatan', berag 'kurus', linsir 'tua'

/w/ : wanen 'pemberani', puwargan 'dapur', duwag 'pintar'

/y/ : yen 'kalau', tayun 'ayn'

\subsubsection{Fonologi Dialek So Ngajah ( DS )}

Deskripsi sistem fonologi DS menyangkut inventarisasi dan distribusi fonem yang akan dipaparkan satu persatu berikut ini.

\subsubsection{Inventarisasi Fonem}

Fonem-fonem dalam dialek So Nggajah pada dasarnya dikelompokkan menjadi dua bagian, yaitu vokal dan konsonan. Sistem vokal dialek ini tersusun dalam 8 fonem vokal, seperti terlihat pada bagan berikut ini.

\section{Bagan Vokal Dialek So Nggajah}

\begin{tabular}{|c|c|c|}
\hline i & & u \\
\hline $\mathrm{e}$ & $\mathrm{a}$ & $\mathrm{o}$ \\
$\mathrm{E}$ & & $\mathrm{O}$ \\
\hline & & \\
\hline & & $\mathrm{a}$ \\
\hline
\end{tabular}


Pembuktian akan status fonemis kedelapan vokal di atas dilakukan dengan menunjukan pasangan minimal dari fonem-fonem tersebut, sedangkan untuk fonem-fonem yang tidak ditemukan pasangan minimalnya dilakukan dengan menunjukan distribusi dari fonem-fonem tersebut, dengan catatan bunyi yang memiliki distribusi lengkap akan dijadikan fonem yang berdiri sendiri.

Kemudian, konsonan dalam dialek ini tersusun dalam sistem sebanyak 19 buah fonem, seperti terlihat pada gambar bagan konsonan berikut.

\section{Bagan Konsonan Dialek So Nggajah}

\begin{tabular}{|c|c|c|c|c|c|c|c|c|c|}
\hline \multirow{2}{*}{\multicolumn{2}{|c|}{ Jenis }} & \multirow{2}{*}{\multicolumn{8}{|c|}{ Daerah Artikulasi }} \\
\hline & & & & & & & & & \\
\hline & & \multirow{2}{*}{$\begin{array}{l}\text { Labial } \\
\text { Labial }\end{array}$} & \multicolumn{2}{|c|}{ Dental } & \multicolumn{2}{|c|}{ Alveolar } & \multirow{2}{*}{$\begin{array}{l}\text { Palatal } \\
\text { Laminal }\end{array}$} & \multirow{2}{*}{$\begin{array}{l}\text { Velar } \\
\text { Dorsal }\end{array}$} & \multirow{2}{*}{ Glotal } \\
\hline & & & Labial & Apikal & Apikal & Laminal & & & \\
\hline \multirow[t]{2}{*}{ Hambat } & $\mathrm{TS}$ & $\mathrm{P}$ & & & $\mathrm{i}$ & & $\mathrm{C}$ & $\mathrm{k}$ & $q$ \\
\hline & $\mathrm{BS}$ & $\mathrm{B}$ & & & $\mathrm{d}$ & & $\mathrm{J}$ & $\mathrm{g}$ & \\
\hline \multirow{2}{*}{$\begin{array}{l}\text { Geser/ } \\
\text { Frikatif }\end{array}$} & $\mathrm{TS}$ & & & & & $\mathrm{S}$ & & & $\mathrm{h}$ \\
\hline & $\mathrm{BS}$ & & & & & & & & \\
\hline Nasal & & $\mathrm{M}$ & & & $\mathrm{n}$ & $\mathrm{N}$ & & & \\
\hline Lateral & & & & & 1 & & & & \\
\hline Getar & & & & & $\mathrm{r}$ & & & & \\
\hline $\begin{array}{l}\text { Semi } \\
\text { Vokal }\end{array}$ & & W & & & & $\mathrm{Y}$ & & & \\
\hline
\end{tabular}

\subsubsection{Distribusi Fonem}

Vokal-vokal dalam dialek ini dapat menempati posisi awal, tengah, dan akhir. Lebih jelasnya berikut ini akan ditampilkan contoh distribusi dialek So Nggajah.

/i/ : ipah 'abang/kakak dari isteri', binih 'benih', uni 'malam'

/u/ : uwa 'ayahnya abang/ibu', kubu 'pondok', madu 'berak',

/e/ : epon 'ia', seda ';mati', jalame 'orang'

/o/ : otan 'perut', moton 'potong', sabo 'sagu'

/e/ : endep 'pendek', lenkon 'bengkong', kadek 'tertawa', be 'daging'

/u/ : unuh 'ompong', nunuq 'susu', niku 'itu'

/a/ : ahsab 'lupa', tanaiq 'siang', kra 'kasar'

/a/ : aden 'telan', tajun 'tendang', pala 'pundak'

Selai vokal, konsonan dalam dialek ini hampir semuanya dapat menempati posisi awal, tengah dan akhir kata. Ada beberapa konsonan yang tidak bisa menempati posisi akhirseperti /c/ , /j/, /n/, /w/ , /y/, dan konsonan yang tidak bisa menempati posisi antepenultima dan penultima seperti /q/ dan /h/. Masing-masing contoh berikut diharapkan dapat memperjelas distribusi konsonan dalam dialek ini. 
/h/ : balus 'basah', kabus 'panas', malinap'terlungkup'

/p/ : piran 'dengar', cupak 'sempit', sasap 'kulum',

$/ \mathrm{t} /$ : tuya 'air', gatap 'takut', bait 'berat'

/d/ : dure 'bubungan', tundun 'pinggul', punsad 'puser'

/c/ : cikut 'tengkuk', muncul 'pangkal'

/j/: jimbar 'lebar', tajap 'tajam'

/k/ : kumpl 'orang tua kakek/nenek', tankah 'dada', pakek 'buta'

/g/ : gamal 'genggam, taga 'tegak', barag 'kurus'

/q/: yoqyoqan 'buai', laguq 'tetapi'

/s/ : salam 'hitam', basah 'bengkak', kadis 'burung'

/h/ :ahsab 'lupa', ningah 'lebar'

/m/ :murip 'hidup', lamat 'lemah', galam 'sakit'

/n/ :nikul 'pikul', mandus 'mandi', wanen 'pemberani'

/n/ :narit 'teriak', kan ekan 'sedang'

/n/ :nutah 'muntah', ninah 'dengar', saran 'dan'

/1/ :liu 'mereka', malagu 'nyanyi', puntul 'tumpul'

/w/ : warsa 'tahun', diwan 'diluar'

/y/ : yoqyoqan 'buai', kayun 'hati'

\subsubsection{Fonologi Dialek Mada Jumba ( DMJ )}

Deskripsi sistem fonologi DMJ menyangkut inventarisasi dan distribusi

fonem yang akan dipaparkan satu per satu berikut ini.

\subsubsection{Inventarisasi Fonem}

Fonem-fonem dalam dialek Mada Jumba pada dasarnya dapat dikelompokkan menjadi dua bagian, yaitu vokal dan konsonan. Sistem vokal dialek ini tersusun dalam 8 fonem vokal, seperti terlihat pada bagian berikut ini.

\section{Bagan Vokal Dialek Mada Jumba}

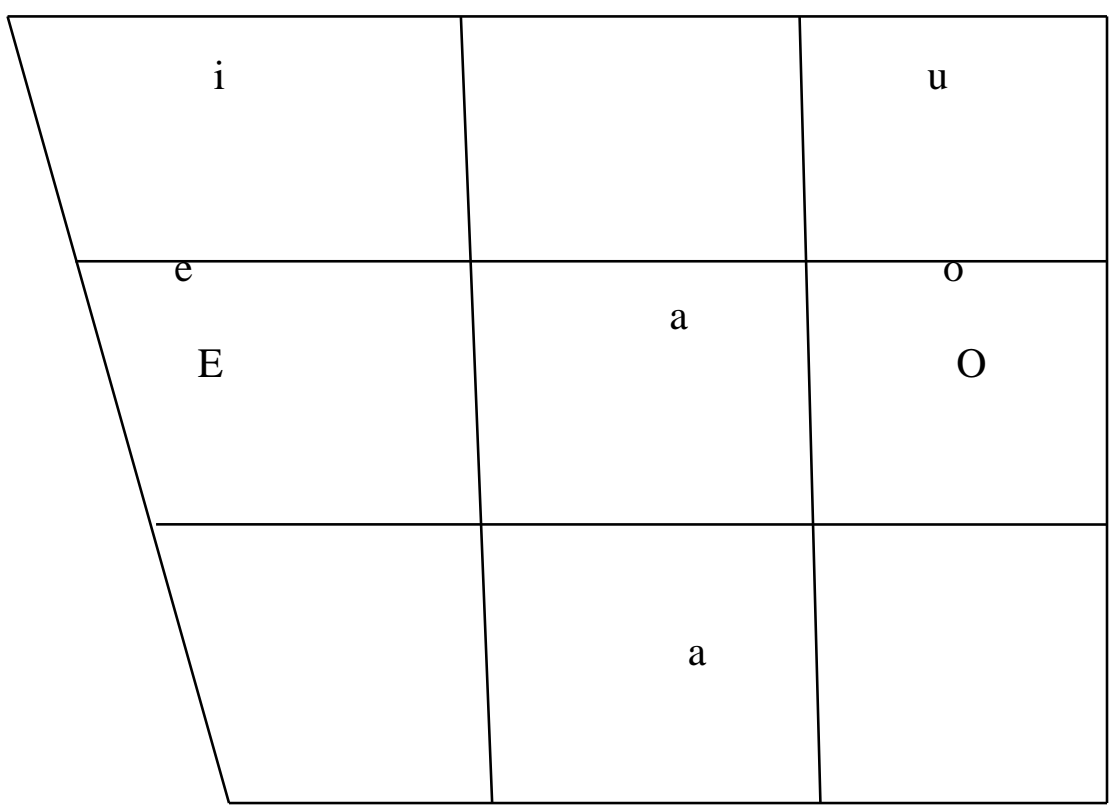


Pembuktian akan status fonemis kedelapan vokal di atas dilakukan dengan menunjukan pasangan minimal dari fonem-fonem tersebut, sedangkan untuk fonemfonem yang tidak ditemukan pasangan minimalnya dilakukan dengan menunjukkan distribusi dari fonem-fonem tersebut, dengan catatan bunyi yang memilki distribusi lengkap akan dijadikan fonem yang berdiri sendiri.

Selanjutnya, konsonan dalam dialek ini tersusun dalam sistem sebanyak 19 buah fonem, seperti terlihat pada gambar bagan konsonan berikut.

\section{Bagan Konsonan Dialek Taropo}

\begin{tabular}{|c|c|c|c|c|c|c|c|c|c|}
\hline \multirow{2}{*}{\multicolumn{2}{|c|}{ Jenis }} & \multirow{2}{*}{\multicolumn{8}{|c|}{ Daerah Artikulasi }} \\
\hline & & & & & & & & & \\
\hline & & \multirow{2}{*}{$\begin{array}{l}\text { Labial } \\
\text { Labial } \\
\end{array}$} & \multicolumn{2}{|l|}{ Dental } & \multicolumn{2}{|c|}{ Alveolar } & \multirow{2}{*}{$\begin{array}{l}\text { Palatal } \\
\text { Laminal }\end{array}$} & \multirow{2}{*}{$\begin{array}{l}\text { Velar } \\
\text { Dorsal }\end{array}$} & \multirow{2}{*}{ Glotal } \\
\hline & & & Labial & Apikal & Apikal & Laminal & & & \\
\hline \multirow[t]{2}{*}{ Hambat } & $\mathrm{TS}$ & $\mathrm{p}$ & & & $\mathrm{i}$ & & $\mathrm{c}$ & $\mathrm{k}$ & $\mathrm{q}$ \\
\hline & BS & $\mathrm{b}$ & & & $\mathrm{d}$ & & $\mathrm{j}$ & $\mathrm{g}$ & \\
\hline \multirow{2}{*}{$\begin{array}{l}\text { Geser/ } \\
\text { Frikatif }\end{array}$} & $\mathrm{TS}$ & & & & & $\mathrm{S}$ & & & $\mathrm{h}$ \\
\hline & BS & & & & & & & & \\
\hline Nasal & & $\mathrm{m}$ & & & $\mathrm{n}$ & $\mathrm{N}$ & $\mathrm{n}$ & & \\
\hline Lateral & & & & & 1 & & & & \\
\hline Getar & & & & & $\mathrm{r}$ & & & & \\
\hline $\begin{array}{l}\text { Semi } \\
\text { Vokal }\end{array}$ & & W & & & & $\mathrm{Y}$ & & & \\
\hline
\end{tabular}

\subsubsection{Distribusi Fanem}

vokal-vokal dalam dialek ini dapat menempati posisi awal, tengah, dan akhir. Lebih jelasnya berikut ini akan ditampilkan contoh distribusi dialek Mada Jumba.

$$
\begin{aligned}
& \text { /i/ : ikoh 'ekor', linun 'berkunang-kunang', nalani 'berenang' } \\
& \text { /u/ : ulian 'karena', lunal 'bakar', matatu 'luka' } \\
& \text { /e/ } \quad \text {; empuq 'pukul', peka 'kakek', nande 'nyala' (me-) } \\
& \text { /o/ } \quad \text { otan 'perut', mabaros 'buru (ber-)', makalo 'lama' } \\
& \text { /E/ : Ebuh 'gemuk', le 'besar'mak 'gEgEr', punggung 'gadE 'besar' } \\
& \text { /u/ : unuh 'ompong', nunu 'tetek', mungu 'pikul' } \\
& \text { /a/ : abuk 'debu', langatan 'tungku', iba 'kamu' } \\
& \text { /a/ : ambubu 'awan', sayun 'awan', uwa 'abangnya ayah/ibu' }
\end{aligned}
$$

Selain vokal, kosonan dalam dialek ini hampir semuanya dapat menempati posisi awal, tengah, dan akhir kata. Ada beberapa konsonan yang tidak bisa menempati posisi akhir seperti /c/, /j/ , /n/ , /w/ , /y/, dan konsonan yang tidak bisa menempati posisi antepenultima dan penultima seperti /q/ dan /h/ . Masing-masing contoh berikut diharapkan dapat memperjelas distribusi konsonan dalam dialek ini.

$$
\begin{aligned}
& \text { /b/ : bauq 'cambang', abin 'jurang', kasiab ';terkejut' } \\
& \text { /p/ : paluh 'keringat', ipid 'igau' (meng-)', sinkep 'elang' } \\
& \text { /t/ : tunkEl 'pinggul', nutah 'muntah', magalut 'peluk' }
\end{aligned}
$$


Mabasan, Vol. 1, No. 2, Juli-Desember 2007: 1-16

/d/ : dada 'dada', udud 'cangkul'

/c/ : canti 'gayung', lacur 'miskin'

/j/ : junus 'gigi yang menonjol ke luar', pejan 'letakkan'

/k/ : kulunan 'kerongkongan', jukut 'sayur', madesah 'sentuh'

/g/ : ganah 'tempat', nigal 'tari', ndag 'terbit'

/q/ : laguq 'tetapi'

/s/ : samba 'lumbung', isap 'lupa', kutus 'delapan'

/h/ : bahat 'berat', linggah 'lebar'

$/ \mathrm{m} /$ : maras 'nenas', gamal 'genggam', ninam 'minum'

/n/ : nian 'nenek', lunaq 'asam', naukin 'panggil'

/n/ : nunju 'kesturi (sejenis tikus berbau)', bunkul 'batang', panjan 'lantang'

/l/ : lanan 'lengan', nilam 'selam', tugal 'potong'

/r/ : rai 'adik', rueras 'dua belas', lanar 'botak'

/w/ : waran 'besar', nuwun 'junjung'

/y/ : yuyu 'kepiting', iyin 'ringan

\subsubsection{Fonologi Dialek Simpasai (DSim)}

Deskripsi sistem fonologi DSim menyangkut inventarisasi dan distribusi fonem yang akan dipaparkan satu per satu berikut ini.

\subsubsection{Inventarisasi Dialek Simpasai}

Fonem-fonem dalam dialek Simpasai pada dasarnya dapat dikelompokkan menjadi dua bagian, yaitu vokal dan konsonan. Sistem vokal dialek ini tersusun dalam 9 fonem vokal, seperti terlihat pada bagan berikut ini.

\section{Bagan Vokal Dialek So Nggajah}

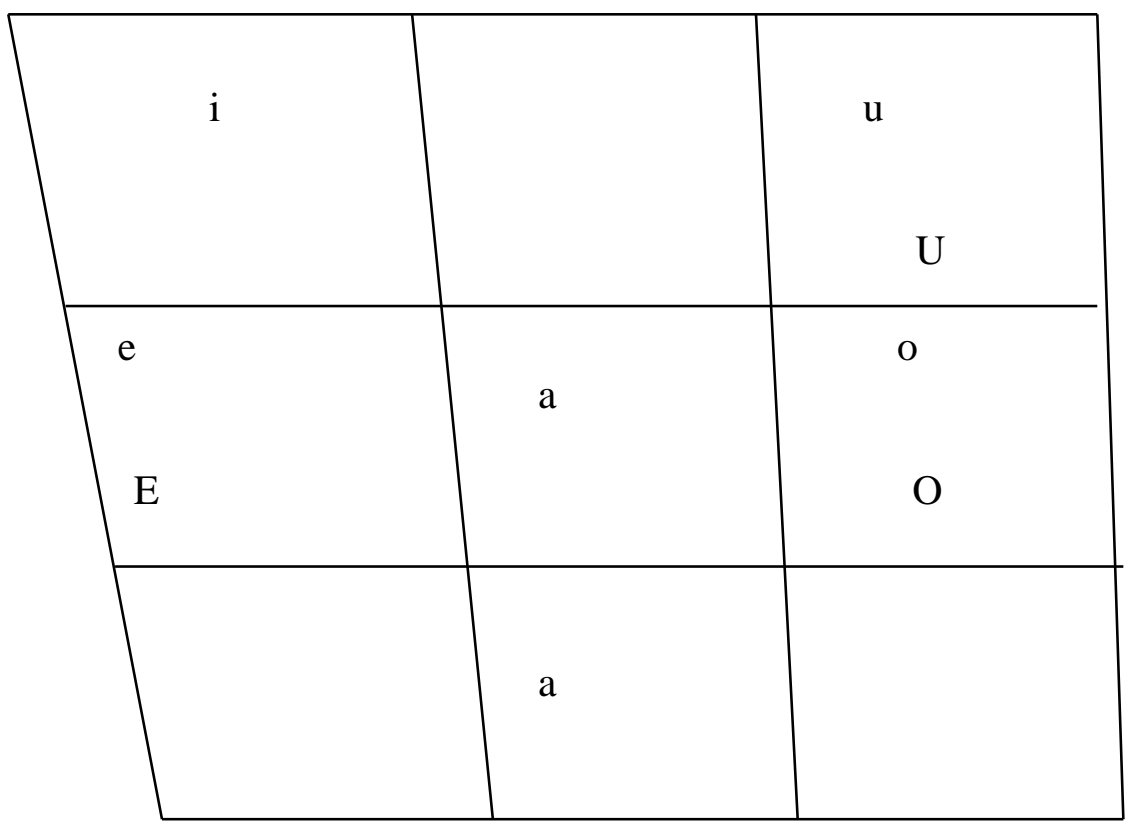

Pembuktian akan status fonemis ke sembilan vokal di atas dilakukan dengan menunjukan pasangan minimal dari fonem-fonem tersebut, sedangkan untuk fonem- 
Mabasan, Vol. 1, No. 2, Juli-Desember 2007: 1-16

fonem yang tidak ditemukan pasangan minimalnya dilakukan dengan menunjukan distribusi dari fonem-fonem tersebut, dengan catatan bunyi yang memiliki distribusi lengkap akan dijadikan fonem yang berdiri sendiri.

Selanjutnya, konsonan dalam dialek ini tersusun dalam sistem sebanyak 19 buah, seperti terlihat pada gambar bagan konsonan berikut.

\section{Bagan Konsonan Dialek Simpasai}

\begin{tabular}{|c|c|c|c|c|c|c|c|c|c|}
\hline \multirow{3}{*}{\multicolumn{2}{|c|}{ Jenis }} & \multicolumn{8}{|c|}{ Daerah Artikulasi } \\
\hline & & \multirow{2}{*}{$\begin{array}{l}\text { Labial } \\
\text { Labial }\end{array}$} & \multicolumn{2}{|c|}{ Dental } & \multicolumn{2}{|c|}{ Alveolar } & \multirow{2}{*}{$\begin{array}{l}\text { Palatal } \\
\text { Laminal }\end{array}$} & \multirow{2}{*}{$\begin{array}{l}\text { Velar } \\
\text { Dorsal }\end{array}$} & \multirow[t]{2}{*}{ Glotal } \\
\hline & & & Labial & Apikal & Apikal & Laminal & & & \\
\hline \multirow{2}{*}{$\begin{array}{l}\text { Hamba } \\
\mathrm{t}\end{array}$} & TS & $\mathrm{p}$ & & & $\mathrm{i}$ & & $\mathrm{c}$ & $\mathrm{k}$ & $q$ \\
\hline & $\mathrm{BS}$ & $\mathrm{b}$ & & & $\mathrm{d}$ & & $\mathrm{j}$ & $\mathrm{g}$ & \\
\hline \multirow{2}{*}{$\begin{array}{l}\text { Geser/ } \\
\text { Frikatif }\end{array}$} & TS & & & & & $S$ & & & $\mathrm{~h}$ \\
\hline & $\mathrm{BS}$ & & & & & & & & \\
\hline Nasal & & $\mathrm{m}$ & & & $\mathrm{n}$ & $\mathrm{N}$ & $\mathrm{n}$ & & \\
\hline Lateral & & & & & 1 & & & & \\
\hline Getar & & & & & $\mathrm{r}$ & & & & \\
\hline $\begin{array}{l}\text { Semi } \\
\text { Vokal }\end{array}$ & & w & & & & $\mathrm{Y}$ & & & \\
\hline
\end{tabular}

\subsubsection{Distribusi Fonem}

Vokal-vokal dalam dialek ini dapat menempati posisi awal, tengah dan akhir. Khusus fonem vokal /o/ yang memiliki alofon /o/ dan /u/, keduanya berbeda dalam pemunculan posisi silabe. Alofon /o/ selalu muncul dalam silabe tertutup dan alofon /u/ dapat muncul dalam silabe terbuka. Sama halnya dengan fonem /u/ yang memiliki alofon /u/ dan /U/, keduanya memiliki perbedaan posisi silabe. Alofon /u/ dapat muncul dalam posisi terbuka, sedangkan alofon /U/ hanya dapat muncul dalam posisi tertutup. Lebih jelasnya berikut ini akan ditampilkan contoh distribusi dialek Simpasai.

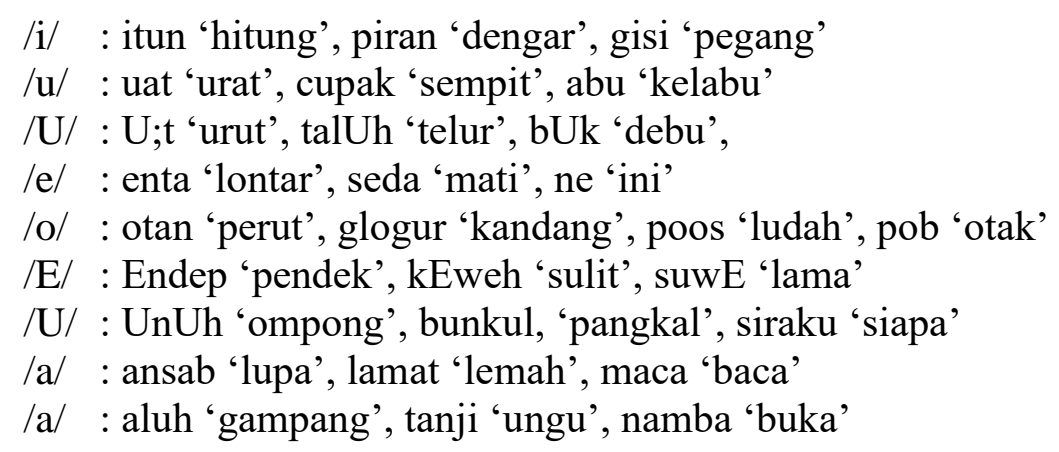

Selain vokal, konsonan dalam dialek ini hampir semuanya dapat menempati posisi awal, tengah dan akhir kata. Ada beberapa konsonanis yang tidak bisa menempati posisi akhir seperti /c/ , /j/ , /w/, /y/ , dan konsonan yang tidak bisa 
menempati posisi antepenultima dan penultima seperti /q/ dan /h/. Masing-masing contoh berikut diharapkan dapat memperjelas distribusi konsonan dalam dialek ini.

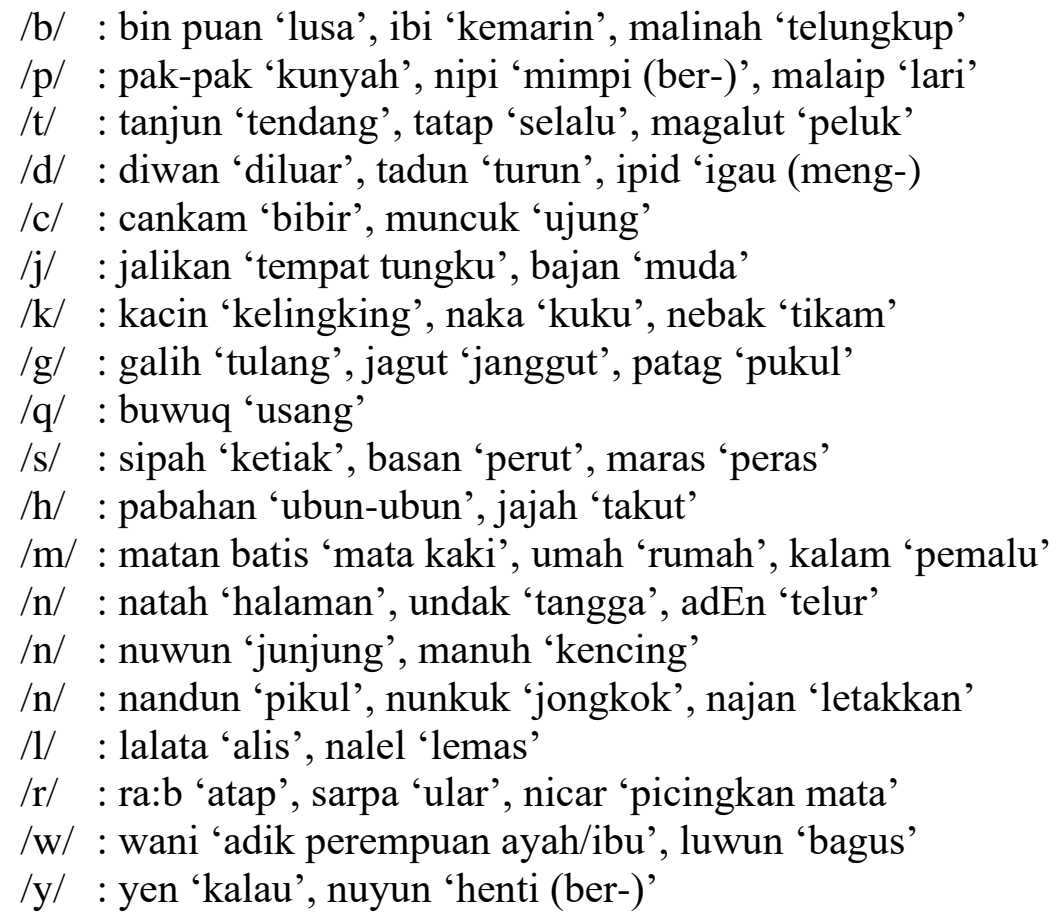

\section{Kesimpulan}

Berdasarkan pendekatan dialektologis, diperoleh 162 buah peta dari 400 data yang mencakup kosakata dasar dan kosakata budaya dasar yang memperlihatkan perbedaan unsur kebahsaan (fonologi dan leksikon) pada empat daerah pengamatan. Dengan berpijak pada perhitungan di alektometri dan didukung oleh bukti kualitatif berupa peta yang memperlihatkan pemilahan antardialek, dapat dikatakan bahwa bahasa Bali memliki empat dialek, yaitu dialek Taropo (DT), dialek So Nggajah (DS), dialek Mada Jumba (DMJ), dan dialek Simpasai (DSim). Keempat dialek ini tidaklah langsung diturunkan sekaligus dari prabahasa Bali-Dompu.

Peneliti sudah membuktikan bahwa munculnya keempat dialek bahasa Bali tersebut melalui jenjang kekerabatan yang bertingkat-tingkat. Pembuktian yang dimaksud dengan melakukan perhitungan rata-rata melalui unsur kedekatan anatardialek yang dihitung berdasarkan persentase terkecil dari hasil dialektometri sehingga dapat disimpulkan prabahasa Bali-Dompu dalam fase perkembangan historis memiliki dua dialek, yakni dialek Taropo So Nggajah Simpasai (DTSSim) dan satu dialek, yakni dialek Mada Jumba (DMJ) yang merupakan dialek tersendiri. Pada fase selanjutnya, DTSSim terpecah menjadi tiga dialek, yaitu dialek Taropo, dialek So Nggajah,dan dialek Simpasai. 


\section{DAFTAR PUSTAKA}

Bawa, I Wayan. 1983. "Bahasa Bali di Bali: Sebuah Analisis Geografi Dialek". Disertasi Doktor. Jakarta: Universitas Indonesi.

Burhanuddin. 2004. Enklave Sumbawa di Pulau Lombok Kajian Linguistik Diakronis. Jakarta : Gramedia Pustaka Utama.

Bynon, T. 1979. Historical Linguisties. Cambridge: University Press.

Crowley, Tcrty, 1987. An Introduction to Historical Linguistics. Papua New Guinea: University of Papua New Guinea Press.

Dhanawati, Ni Made. 2002. "Variasi Dialektal Bahasa Bali di Daerah Transmigrasi Lampung Tengah”. Disertai Doktor. Yogyakarta: Universitas versitas Gajah Mada.

Dyen, Isidore. 1971. The Austronesian Languages and Proto-Austronesian.Current Trends in Linguistics 8: 5-54.

Damhujin. 2005. "Distribusi Bahasa Bali dan Bahasa Sumbawa di Pulau Lombok". Mataram: Knator Bahasa Provinsi NTB.

Denes, I Made dkk. 1985. Geografi Dialek Bahasa Bali. Jakarta: Pusat Pembinaan dan Pengembangan Bahasa, Departemen Pendidikan dan Kebudayaan.

Departemen Pendidikan dan Kebudayaan. 1984. Dampak Modernisasi Terhadap Hubungan Kekerabatan di Bali.

Herusantoso, Suparman. dkk. 1987. "Pemetan Bahasa-Bahasa di Nusa Tenggara Barat”. Jakarta: Pusat Pembinaan dan Pengembangan Bahasa.

Kridalaksana, Harimurti. 1984. Kamus Linguistik. Jakarta: PT Gramedia Kersten, J. 1984. Tata Bahasa Bali. Flores: Nusa Indah.

Lauder, Multamia RMT. 1998. “Usaha Melacak Bahasa-Bahasa Nusantara”. Jakarta: PRT.BA.

Lehman, Winfred P. 1973. Historical Linguistcs: An Introducation. New York: Holt,Rinehart, and Winston Inc.

Mahsun. 1994. "Penelitian Dialek Geografis Bahasa Sumbawa". Disertasi Doktor. Yogyakarta: Universitas Gadjah Mada.

Mahsun. 1995. Dialektologi Diakronis: Sebuah Pengantar. Yogyakarta: Gadjha Mada University Press.

Mahsun. 1997. "Linguistik Diakronis dan Pengembangan Materi Muana Lokal Bahasa Daerah yang Berwawasan Kebangsaan" Makalah pada Seminar 
Mabasan, Vol. 1, No. 2, Juli-Desember 2007: 1-16

Internasional Bahasa dan Budaya di Dunia Melayu, di Universitas Mataram, Juli 1997.

Mahsun. 1998. "Pengembangan Materi MuTn Lokal yang Berdimensi Kebhinekatunggalikaan dan Pengajarannya: Penyusunan Bahan Pelajaran Bahasa Sasak dengan Memanfaatkan Variasi Bahasa yang Berkerbat". Laporan Riset Unggulan Terpadu Tahun I, 1998, Dewan Riset Nasional: Jakarta.

Mahsun. 2005. Metodologi Penelitian Bahasa. Jakarta : Raja Grafindo Persada.

Mbete, Aron Meko. 1990. "Rekonstruksi Protobahasa Bali-Sasak Sumbawa". Jakarta: Universitas Indonesia (Disertai Doktor) Nothofer, Bernd. 1975. The Reconstruction of Proto-Malayo-Javanic.S'Granvehage-Martinus Nijhoff.

Mbete, Aron Meko. 1987. Cita-cita penelitian Dialek. Dewan Bahasa: 31,2 Sudika, I Nyoman,1998. "Isolek Bali di Lombok: Kajian Dialektologi Diakronis". Tesis S2. Denpasar: Universitas Udayana.

Tawangsih Lauder, Multamia R.M.1990.'Pemetaan dan Distribusi Bahasa-bahasa di Tangerang". Disertai Doktor. Jakarta: Universitas Indonesia.

Tawangsih Lauder, Multamia RM 2002. "Revaluasi Konsep Pemilah Bahasa dan Dialek untuk Bahasa Nusantara". Makara Sosial Humaniora, Vol.6 No.1, Juni 2002.

Teeuw, A. 1951. Dialekt-Atlas van of Lombok. Jakarta: Biro Reproduksi Djawatan Tofografi.

Teeuw, A. 1958. Lombok: Een Diaelect Geografische Studie. S'Gravenhage: Martinus Nijhoff.

Wacana, H. L. 1988. Sejarah Daerah Nusa Tenggara Barat. Proyek Inventarisasi dan Dokumentasi Kebudayaan Nusa Tenggara Barat. 